\title{
Employee Engagement, Satisfaction and Loyalty: Preliminary Findings
}

\author{
Syahrizal Syahrizal ${ }^{1}$, Dina Patrisia ${ }^{2}$, Abror Abror $^{3}$ \\ ${ }^{1}$ Universitas Negeri Padang, Padang, Indonesia, $\triangle$ syahrizal@fe.unp.ac.id \\ ${ }^{2}$ Universitas Negeri Padang, Padang, Indonesia, $₫$ patrisiadina@yahoo.com \\ 3Universitas Negeri Padang, Padang, Indonesia, $₫$ abror094@gmail.com
}

\begin{abstract}
Employee loyalty is an important factor in managing the organisation such as a university. There are some antecedents of employee loyalty, such as employee engagement and job satisfaction. This study examines the relationship between employee engagements, job satisfaction and employee loyalty. This preliminary study has been conducted in a university in Indonesia. We employed lecturers of one state university in West Sumatera as the sample of study. We used Structural Equation Model (SEM) Partial Least Square (PLS) with Smart PLS 3 as the data analysis software package. This study found that employee engagement has a significant impact on job satisfaction. There is no significant direct effect of employee engagement on employee loyalty. Surprisingly, we also found that employee engagement has a significant mediating impact on the link between employee engagement and employee loyalty. Furthermore, some limitations and future research are discussed.
\end{abstract}

Keywords: employee engagement, job satisfaction, employee loyalty, structural equation model (SEM), partial least square (PLS)

\section{Introduction}

The higher education sector becomes a highly competitive sector nowadays (Asrar-ul-Haq et al., 2017). University as one of the higher education entities has to develop innovative programmes, such as digital based service quality, which might create a better competitive advantage. One important factor in creating a competitive advantage is human resource management. One of the human resources in a university is lecturer. There are some indicators of the quality of lecturer. For example, we can see the quality of the lecturer in his/her ability to teach and his/her loyalty to the university.

Universitas Negeri Padang (UNP) as one of the state universities in Indonesia has also faced the competition problem. It has to survive and retain its customers. Today UNP has 1125 lecturers and 405 supporting staffs with more than 35,000 enrolled students. One problem in the universities such as UNP right now is the lecturer's loyalty. According to Ineson et al. (2013) there are several influenced factors of employee loyalty, such as employee satisfaction and engagement.

Furthermore, employee satisfaction is not an instant result. Some previous studies have asserted that there are several antecedents of employee satisfaction, such as employee engagement and selfefficacy (De Simone et al., 2018, Perera et al., 2018, Suhartanto et al., 2018). Recently, the university's management has a program to change the university's mindset from the teacher's university to the research university. This program is in line with the performance contract between rector and the Directorate General of Higher Education and it will be followed by the contract between rector and deans in Universitas Negeri Padang. Accordingly to achieve this vision, it should be followed by the loyalty of lecturer to participate in achieving the university's vision. However, study on employee loyalty is still neglected, hence, this study aims to investigate the link between employee loyalty and its antecedents, including employee engagement and employee satisfaction.

\section{Employee Loyalty}

Employee loyalty refers to an employee's feeling of attachment to his/her employer (Masakure, 2016). According to Ineson et al. (2013), there are some antecedents of employee loyalty, such as employee commitment, personal satisfaction, work environment, social benefit and monetary rewards. Furthermore, Lee et al. (2017), Longo and Mura (2011) dan Bhattacharya (2015) assert that employee will stay in the company when he/she satisfied with his/her job. Employee loyalty can be 
measured by using some items, including (1) want to do the job more than the organisation expectation to make sure the organisation successfulness (2) want to make the company as his/her own carrier (3) care with the organization condition (4) want to stay in the organization (Jun et al., 2006).

\section{Employee Satisfaction}

Employee satisfaction becomes an important factor because managements' view on human resource has changed. In the past, they argued that human resource is only a cost for the company; whilst, today they assert that human resource is an asset for the business. Some previous studies also argue that employees may become a competitive advantage which is not easy to imitate by the competitor (Suhartanto et al., 2018). When the employees satisfied with the company, they will do their best and it will increase the company's performance (De Simone et al., 2018). Employee satisfaction refers to the employee's feeling about the job based on his/her experience (like or dislike) (Drydakis, 2017, Asrar-ul-Haq et al., 2017, Coetzee and Stoltz, 2015). Some prior studies argue that employee satisfaction has some antecedents, such as self-efficacy, employee engagement and social support (De Simone et al., 2018, Orgambídez-Ramos and de Almeida, 2017, Malinen and Savolainen, 2016). Employee satisfaction has also related to some consequences such as employee loyalty and organizational citizenship behavior (Ocampo et al., 2018, Xie et al., 2017, Ineson et al., 2013). In addition, according to Xie et al. (2017), employee satisfaction can be measured by using some indicators, such as overall satisfaction of the job.

\section{Employee Engagement}

Employee engagement is a positive, fulfilling, work-related state of mind that is characterized by vigor, dedication, and absorption (Schaufeli et al., 2002). It relates to the positive emotional relationship between employees and their job (Orgambídez-Ramos and de Almeida, 2017). Accordingly, employee engagement has three main dimensions, including vigor, dedication and absorption (Orgambídez-Ramos and de Almeida, 2017, Lu et al., 2018). Furthermore, Albrecht and Marty (2017) have asserted that employee engagement has a close relationship with the psychological factor, such as satisfaction which has an impact on employee's performance. Cahill et al. (2015) also argue that employee engagement will affect the employee's work-life balance. Albrecht and Marty (2017) argue that employee engagement can be measured by using four indicators, such as "my job inspires me".

Some prior studies have found that employee engagement has a relationship with employee satisfaction (De Simone et al., 2018, Orgambídez-Ramos and de Almeida, 2017, Ocampo et al., 2018). For example, Orgambídez-Ramos and de Almeida (2017) have revealed that employee engagement is one significant antecedent of employee satisfaction. They have conducted their study to 215 nursing professionals in Portugal. In line with Orgambídez-Ramos and de Almeida (2017), Suhartanto et al. (2018) have also found that employee satisfaction is influenced by employee engagement. They studies 408 frontline staffs of retail stores. Moreover, Perera et al. (2018) have investigated 574 teachers in Australia. By using Structural Equation Modeling as the data analysis tools they found that the teachers' satisfaction with their job is affected by the teachers' engagement. Therefore from the discussion above, we propose a hypothesis that employee engagement has a positive and significant impact on employee satisfaction (H1).

\section{Employee Engagement and Employee Loyalty}

Employee engagement is also related to employee loyalty (Milliman et al., 2018, Karatepe and Ngeche, 2012, De Simone et al., 2018, Salmela-Aro and Upadyaya, 2018). Milliman et al. (2018) and Karatepe and Ngeche (2012) have asserted that employee engagement has a relationship with job embeddedness. When an employee engages with his/her job in the company, he/she will have a better job embeddedness, whilst, job embeddedness is related to the employee loyalty. Moreover Shahpouri et al. (2016) have examined the mediating role of work engagement on the link between job resources 
and turn over intention. They found that work engagement has a significant impact on turn over intention. On the other hand, turn over intention relates to employee loyalty. Hence, we argue that employee engagement has a direct impact on employee loyalty. Therefore, we posit that employee engagement is a significant and positive antecedent of employee loyalty $(\mathrm{H} 2)$.

\section{Employee Satisfaction and Employee Loyalty}

Several previous studies have revealed that employee satisfaction has a significant and positive influence on employee loyalty (Collins et al., 2014, Masakure, 2016, Ineson et al., 2013). Masakure (2016) argues that the employees will be loyal to the organisation when they satisfied with their job and the work environment. Moreover, in marketing context, the prior studies also found that customer satisfaction will have a positive effect on customer loyalty (Han et al., 2017). Hence, we argue that employee satisfaction has a significant and positive impact on employee loyalty (H3).

\section{Methods}

\section{Sampling and Data Collection Procedures}

This preliminary study has been conducted in a state university in Padang West Sumatera. It is a part of the main study where the study's population is all permanent lecturers in this university. However, we have employed only 30 respondents as the samples for this preliminary study. For the data collection, we used several steps: First, we sent the questionnaires to 30 lecturers who agreed to participate in this study. Second, we input the data to the SPSS software program.

\section{Measurement}

This study has employed three constructs (i.e., employee engagement, employee satisfaction and employee loyalty). We adopted the measurement for employee engagement from Albrecht and Marty (2017). The sample of items from this construct is "at my job I feel strong and vigorous". The employee satisfaction construct has been adopted from Xie et al. (2017) and Messersmith et al. (2011). The example of the measurement items is "All things considered, I feel pretty good about this job." Finally, the employee loyalty construct has been measured by using three loyalty indicators from Jun et al. (2006). We employed Structural Equation Modelling (SEM) PLS with Smart PLS-3 to analyse the data (Hair et al., 2014)

However, before the main analysis, we have done some preliminary tests, such as normality, heteroschedasticity, multicollinearity and outlier test (Wardi et al., 2018b, Patrisia and Dastgir, 2017)

\section{Result and Discussion}

\section{Result}

This study has analysed the data by using SEM PLS. However, before the main analysis, we have conducted some prior tests. For example we examined the validity and reliability of the data. Table 1 shows the construct validity and reliability. We found all the constructs are valid (the Average Variance Extracted values are $\geq 0.50$ ) and reliable based on two values (Cronbach's alpha and Construct Reliability $\geq 0.70$ ) (Abror and Akamavi, 2015, Wardi et al., 2018a).

Table 1 Construct validity and Reliability

\begin{tabular}{lcccc}
\hline Variable & $\begin{array}{c}\text { Cronbach's } \\
\text { Alpha }\end{array}$ & $\begin{array}{l}\text { Rho } \\
\text { A }\end{array}$ & CR & AVE \\
\hline Employee Loyalty & 0.91 & 0.92 & 0.95 & 0.85 \\
\hline Employee Satisfaction & 0.91 & 0.97 & 0.94 & 0.84 \\
\hline Employee Engagement & 0.90 & 0.90 & 0.93 & 0.78 \\
\hline CR= Construct Reliability, AVE= Average Variance Extracted &
\end{tabular}

Moreover, we have also examined the discriminant validity of the constructs by using the square root of AVE. Table 2 shows the value of square root of AVE in the diagonal should be greater than the correlation (Hair et al., 2013). 
Table 2 Discriminant Validity

\begin{tabular}{clll}
\hline Variable & $\mathbf{1}$ & $\mathbf{2}$ & $\mathbf{3}$ \\
\hline Employee Loyalty & 0.92 & & \\
\hline Employee Satisfaction & 0.72 & 0.92 & \\
\hline Employee Engagement & 0.63 & 0.70 & 0.88 \\
\hline
\end{tabular}

Note: Diagonal is the square root of AVE

The primary analysis in Table 3 has revealed that the employee engagement has a positive and significant effect on employee satisfaction (H1). Moreover, the employee engagement has not significantly affected the employee loyalty (H2). Finally, we also found that employee satisfaction has a positive and significant impact on the employee loyalty (H3). Surprisingly, even though employee engagement has no significant direct impact on employee loyalty, it has a significant indirect effect on employee loyalty through employee satisfaction as a mediator. This finding has been tested by using Sobel's Test with significant value $0.005(<0.05)$. for the research model please see Figure 1.

Table 3 Hypothesis Testing

\begin{tabular}{cccc}
\hline Hypothesis & Coefficient & $\begin{array}{c}\text { T } \\
\text { Statistic }\end{array}$ & $\begin{array}{c}\mathbf{P} \\
\text { Value }\end{array}$ \\
\hline EmpSat -> EmpLoy & 0.55 & 2.78 & 0.01 \\
\hline Engage -> EmpLoy & 0.24 & 1.20 & 0.23 \\
\hline Engage -> EmpSat & 0.70 & 6.76 & 0.00 \\
\hline
\end{tabular}

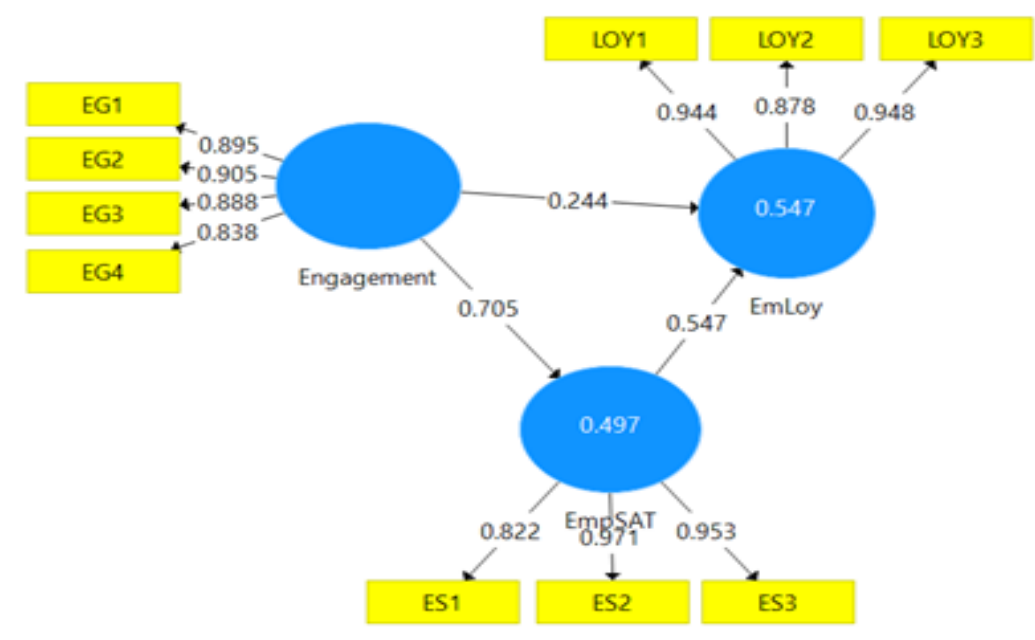

\section{Discussion}

Figure 1 Research Model

The findings of this study revealed that employee engagement has a significant influence on employee satisfaction (H1). This finding reflects the previous findings, such as Orgambídez-Ramos and de Almeida (2017); Ocampo et al. (2018) and Suhartanto et al. (2018) who have examined the link between employee engagement and employee satisfaction. They argue that when an employee is engaged with the company, it will affect his/her satisfaction. Accordingly, to make sure that the employees have a high employee satisfaction, the company has to concern with the engagement programs. Moreover, Perera et al. (2018) have highlighted that the teacher's satisfaction has been affected by the teacher's engagement. Therefore, employee engagement is a significant and positive antecedent of employee satisfaction.

The findings highlight that employee engagement has not significantly impacted the employee loyalty (H2). This finding is not in the lines with some prior studies (Milliman et al., 2018, Karatepe and Ngeche, 2012, Shahpouri et al., 2016) who argue that employee engagement has a significant impact on employee loyalty. However, although the employee engagement has no significant direct 
impact on employee loyalty, it has a significant indirect impact through employee satisfaction as the mediating variable. Therefore, to increase employee loyalty, the company has to address the employee engagement, hence, it will have a positive impact on employee satisfaction as a significant antecedent of employee loyalty.

Finally, we found that employee satisfaction is a significant and positive antecedent of employee loyalty (H3). This finding is congruent with several prior studies (Masakure, 2016, Ineson et al., 2013). For instance, Han et al. (2017) and Masakure (2016) have asserted that satisfaction is an antecedent of loyalty. Therefore, when an employee is satisfied with his/her job, he/she will be loyal to the organisation. The employees will show their loyalty with some indicators, such as do their job seriously and want to recommend the organisation to other people.

\section{Conclusions}

In conclusion, we have revealed some important findings; including there is a significant direct effect of employee engagement on employee satisfaction. We also found that employee satisfaction has a significant impact on employee loyalty. Finally, even though there is no significant direct impact of employee engagement on employee loyalty, surprisingly, we found a significant direct impact on that relationship through employee satisfaction as the mediator. Furthermore, this research also has some limitations, such as the number of samples is still small, hence, for the main study, we suggest to use a larger sample size. This study has only been conducted in one university and for future study, it can be extended to some universities in Indonesia to get more generalize results. Finally, this study only focused on employee engagement and satisfaction as the antecedents of employee loyalty. For future research, it can be expanded to some new variables, such as self-efficacy and Organisational Citizenship behaviour (OCB).

\section{References}

Abror \& Akamavi, R. K. 2015. Psychological safety and organisational performance in indonesian companies: Preliminary findings. Applied psychology. World Scientific.

Albrecht, S. L. \& Marty, A. 2017. Personality, self-efficacy and job resources and their associations with employee engagement, affective commitment and turnover intentions. The International Journal of Human Resource Management, 1-25.

Asrar-ul-Haq, M., Kuchinke, K. P. \& Iqbal, A. 2017. The relationship between corporate social responsibility, job satisfaction, and organisational commitment: Case of pakistani higher education. Journal of Cleaner Production, 142, 2352-2363.

Bhattacharya, Y. 2015. Employee engagement as a predictor of seafarer retention: A study among indian officers. The Asian Journal of Shipping and Logistics, 31, 295-318.

Cahill, K. E., McNamara, T. K., Pitt-Catsouphes, M. \& Valcour, M. 2015. Linking shifts in the national economy with changes in job satisfaction, employee engagement and work-life balance. Journal of Behavioural and Experimental Economics, 56, 40-54.

Coetzee, M. \& Stoltz, E. 2015. Employees' satisfaction with retention factors: Exploring the role of career adaptability. Journal of Vocational Behaviour, 89, 83-91.

Collins, B. J., Burrus, C. J. \& Meyer, R. D. 2014. Gender differences in the impact of leadership styles on subordinate embeddedness and job satisfaction. The Leadership Quarterly, 25, 660-671.

De Simone, S., Planta, A. \& Cicotto, G. 2018. The role of job satisfaction, work engagement, selfefficacy and agentic capacities on nurses' turnover intention and patient satisfaction. Applied Nursing Research, 39, 130-140.

Drydakis, N. 2017. Trans employees, transitioning, and job satisfaction. Journal of Vocational Behaviour, 98, 1-16.

Hair, J. F., Hult, G. T. M., Ringle, C. \& Sarstedt, M. 2013. A primer on partial least squares structural equation modeling ( $p l s$-sem), SAGE Publications.

Hair , J. F. J., Sarstedt, M., Hopkins, L. \& G. Kuppelwieser, V. 2014. Partial least squares structural equation modeling (pls-sem). European Business Review, 26, 106-121. 
Han, H., Meng, B. \& Kim, W. 2017. Bike-traveling as a growing phenomenon: Role of attributes, value, satisfaction, desire, and gender in developing loyalty. Tourism Management, 59, 91-103.

Ineson, E. M., Benke, E. \& László, J. 2013. Employee loyalty in hungarian hotels. International Journal of Hospitality Management, 32, 31-39.

Jun, M., Cai, S. \& Shin, H. 2006. Tqm practice in maquiladora: Antecedents of employee satisfaction and loyalty. Journal of Operations Management, 24, 791-812.

Karatepe, O. M. \& Ngeche, R. N. 2012. Does job embeddedness mediate the effect of work engagement on job outcomes? A study of hotel employees in cameroon. Journal of Hospitality Marketing \& Management, 21, 440-461.

Lee, T. W., Hom, P., Eberly, M. \& Li, J. 2017. Managing employee retention and turnover with 21st century ideas. Organisational Dynamics.

Longo, M. \& Mura, M. 2011. The effect of intellectual capital on employees' satisfaction and retention. Information \& Management, 48, 278-287.

Lu, X., Xie, B. \& Guo, Y. 2018. The trickle-down of work engagement from leader to follower: The roles of optimism and self-efficacy. Journal of Business Research, 84, 186-195.

Malinen, O.-P. \& Savolainen, H. 2016. The effect of perceived school climate and teacher efficacy in behaviour management on job satisfaction and burnout: A longitudinal study. Teaching and Teacher Education, 60, 144-152.

Masakure, O. 2016. The effect of employee loyalty on wages. Journal of Economic Psychology, 56, 274298.

Messersmith, J. G., Patel, P. C., Lepak, D. P. \& Gould-Williams, J. 2011. Unlocking the black box: Exploring the link between high-performance work systems and performance. J Appl Psychol, 96, 1105-18.

Milliman, J., Gatling, A. \& Kim, J. 2018. The effect of workplace spirituality on hospitality employee engagement, intention to stay, and service delivery. Journal of Hospitality and Tourism Management, 35, 56-65.

Ocampo, L. A., Tan, T. A. G. \& Sia, L. A. 2018. Using fuzzy dematel in modeling the causal relationships of the antecedents of organisational citizenship behaviour (ocb) in the hospitality industry: A case study in the philippines. Journal of Hospitality and Tourism Management, 34, 1129.

Orgambídez-Ramos, A. \& de Almeida, H. 2017. Work engagement, social support, and job satisfaction in portuguese nursing staff: A winning combination. Applied Nursing Research, 36, 37-41.

Patrisia, D. \& Dastgir, S. 2017. Diversification and corporate social performance in manufacturing companies. Eurasian Business Review, 7, 121-139.

Perera, H. N., Granziera, H. \& Mcllveen, P. 2018. Profiles of teacher personality and relations with teacher self-efficacy, work engagement, and job satisfaction. Personality and Individual Differences, 120, 171-178.

Salmela-Aro, K. \& Upadyaya, K. 2018. Role of demands-resources in work engagement and burnout in different career stages. Journal of Vocational Behaviour.

Schaufeli, W. B., Salanova, M., González-romá, V. \& Bakker, A. B. 2002. The measurement of engagement and burnout: A two sample confirmatory factor analytic approach. Journal of Happiness Studies, 3, 71-92.

Shahpouri, S., Namdari, K. \& Abedi, A. 2016. Mediating role of work engagement in the relationship between job resources and personal resources with turnover intention among female nurses. Applied Nursing Research, 30, 216-221.

Suhartanto, D., Dean, D., Nansuri, R. \& Triyuni, N. N. 2018. The link between tourism involvement and service performance: Evidence from frontline retail employees. Journal of Business Research, $83,130-137$.

Wardi, Y., Abror, A. \& Trinanda, O. 2018a. Halal tourism: Antecedent of tourist's satisfaction and word of mouth (wom). Asia Pacific Journal of Tourism Research, 23, 463-472. 
Wardi, Y., Susanto, P., Abror, A. \& Abdullah, N. L. 2018b. Impact of entrepreneurial proclivity on firm performance: The role of market and technology turbulence Pertanika J Soc. Sci. \& Hum, 26, 241-250.

Xie, B., Zhou, W., Huang, J. L. \& Xia, M. 2017. Using goal facilitation theory to explain the relationships between calling and organisation-directed citizenship behaviour and job satisfaction. Journal of Vocational Behaviour, 100, 78-87. 